DOI: $10.15421 / 4219029$

УДК 539.3

В. С. Зеленский, канд. ффиз.-мат. наук,

В. А. Декрет, д-р физ.-мат. наук, В. М. Быстров, канд. фриз.-мат. наук

\title{
ПРОСТРАНСТВЕННАЯ ЗАДАЧА УСТОЙЧИВОСТИ КОМПОЗИТНОГО МАТЕРИАЛА, АРМИРОВАННОГО ДВУМЯ ПАРАЛЛЕЛЬНЫМИ КОРОТКИМИ ВОЛОКНАМИ
}

С использованием основных соотношений трехмерной линеаризированной теории устойчивости и модели кусочно-однородной среды решена пространственная задача устойчивости композитного материала с армирующими волокнами конечных размеров. Исследована зависимость критической деформации композитного материала от геометрических характеристик армирующих волокон. Проведено сравнение с результатами, полученными в рамках модели “коротких волокон”. Для решения задачи устойчивости применен численный подход на основе метода сеток.

Ключевые слова: композитный материал, короткие волокна, критическая деформация, трехмерная линеаризированная теория устойчивости, численный подход.

Введение. Исследованию явления потери устойчивости во внутренней структуре композитных материалов (КМ) посвящена работа [3], в которой с привлечением моделей "бесконечно длинных волокон" и "волокон конечных размеров" проведен сравнительный анализ результатов по устойчивости КМ, полученных в рамках плоской задачи (плоская дефрормация). В [4] излагаются конкретные результаты для композитов различной структуры, полученные в рамках модели коротких волокон. Исследован ряд модельных задач устойчивости композитных материалов, описаны математические методы их решения, ориентированные на компьютерную реализацию. В [5] с использованием модели коротких волокон решены плоская и пространственная задачи устойчивости для одного изолированного армирующего волокна в бесконечной матрице при одноосном сжатии. Результаты получены с использованием общих уравнений трехмерной линеаризированной теории устойчивости деформируемых тел (ТЛТУДТ) [2] и модели кусочно-однородной среды. Указанный подход является наиболее строгим и позволяет оценить точность результатов, полученных с применением различных приближенных теорий и расчетных схем.

В продолжение исследований, проведенных в [3 - 5], в настоящей работе рассматривается композитный материал с армирующими короткими волокнами при их малой концентрации. Исследуется взаимодействие между двумя параллельными одинаковыми волокнами, которые размещены вдоль сжимающей нагрузки. Задача решена в пространст-

() В. С. Зеленский, В. А. Декрет, В. М. Быстров, 2019 
венной постановке. Рассмотрен сравнительно жесткий композитный материал, в связи с чем, для решения задачи устойчивости применен второй вариант теории малых докритических деформаций [2], когда докритическое состояние определяется по геометрически линейной теории. Наполнитель (армирующие волокна) и связующее (матрица) моделируются линейно-упругими изотропными телами.

Сложность получения аналитических решений для задач указанного класса предполагает использование современных численных методов. В данной работе для численного решения рассматриваемых задач использован метод сеток на основе модифицированного вариационно-разностного подхода [1, 4].

Постановка задачи. Рассматривается пространственная задача потери устойчивости во внутренней структуре композитного материала для случая двух одинаковых изолированных волокон в бесконечной матрице в соответствии с расчетной схемой, представленной на рис. 1 ( / и $m$ - размеры волокон, $r$ - расстояние между волокнами).

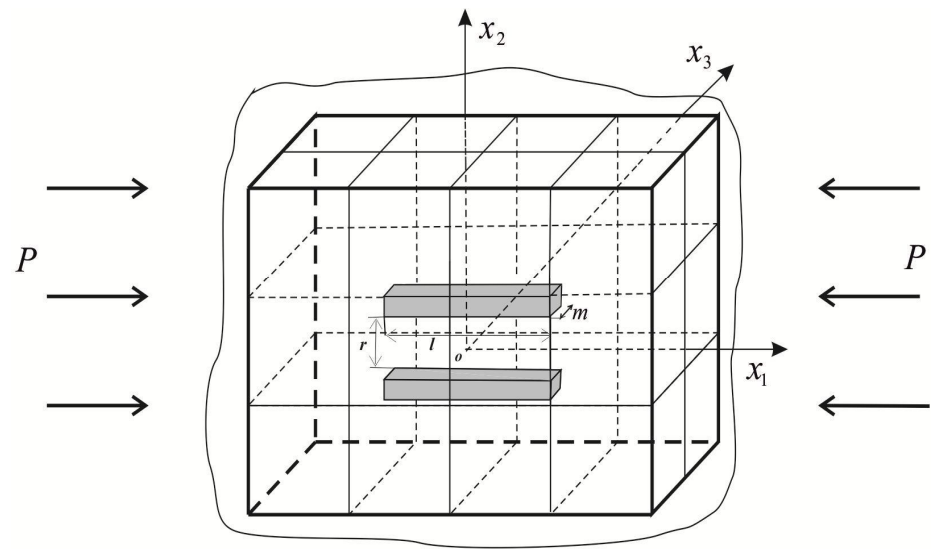

Рис. 1 - Расчетная схема и условия нагружения композита

Исходя из условий симметрии нагружения и регулярности структуры КМ, задачу устойчивости решаем для элемента материала, которому соответствует расчетная область конечных размеров. Указанная расчетная область показана на рис. 1.

Размеры расчетной области выбраны таким образом, что дальнейшее их увеличение существенно не влияет на величину критической нагрузки, которая полностью определяется характеристиками рассматриваемой модели. Армирующие элементы конечных размеров в бесконечной матрице представлены волокнами квадратного поперечного сечения в соответствии с формой, изображенной на рис. 1. Внешняя нагрузка интенсивности $P$ приложена только к матрице и является "мертвой", что обеспечивает выполнение достаточных условий применимости статического метода решения задач ТЛТУДТ. В изложенной постановке задача устойчивости рассмотрена при неоднородном док- 
ритическом состоянии, которое определяется из следующих соотношений линейной теории упругости:

$$
\begin{gathered}
\sigma_{i j, i}^{0}=0, \\
\sigma_{i j}^{0}=\delta_{i j} \lambda \varepsilon_{n n}^{0}+2 \mu \varepsilon_{i j}^{0}, \quad 2 \varepsilon_{i j}^{0}=u_{i, j}^{0}+u_{j, i}^{0},
\end{gathered}
$$

где $\lambda=\frac{E v}{(1-2 v)(1+v)}, \quad \mu=\frac{E}{2(1+v)}$.

Верхним индексом "0" обозначены компоненты напряжений, деформаций и перемещений для докритического состояния, индексы "a" и "m" указывают соответственно на их принадлежность волокну или матрице. Величины $\sigma_{i j}^{0 m}, u_{j}^{0 m}$ с учетом того, что внешняя нагрузка приложена к матрице на бесконечности, могут быть представлены в виде:

$$
\sigma_{i j}^{0 m}=\sigma_{i j}^{\infty}+\sigma_{i j}^{10 m}, u_{j}^{0}=u_{j}^{\infty}+u_{j}^{10 m},
$$

где $\sigma_{i j}^{10 m}, u_{j}^{10 m}$ - компоненты докритического состояния, соответствующие возмущениям напряженно-деформированного состояния, обусловленным наличием волокон конечных размеров. Величины $\sigma_{i j}^{\infty}$, $u_{j}^{\infty}$ находятся из выражений

$$
\begin{gathered}
\sigma_{11}^{\infty}=-P ; \sigma_{22}^{\infty}=\sigma_{33}^{\infty}=0 ; \sigma_{i j}^{\infty}=0 ; i, j=1,2,3, i \neq j, \\
u_{1}^{\infty}=A_{1} x_{1} ; u_{2}^{\infty}=A_{2} x_{2} ; u_{3}^{\infty}=A_{3} x_{3},
\end{gathered}
$$

где величины $A_{1}, A_{2}, A_{3}$ определяются из первого выражения (2) с учетом первых трех выражений (4).

Условия полного сцепления на контакте связующего и наполнителя запишем в виде:

$$
\begin{aligned}
& \sigma_{11}^{\infty}+\sigma_{11}^{10 m}=\sigma_{11}^{0 a} ; \sigma_{12}^{10 m}=\sigma_{12}^{0 a} ; \sigma_{13}^{10 m}=\sigma_{13}^{0 a} ; u_{j}^{0 m}=u_{j}^{0 a} \\
& \text { при } x_{1}=|l / 2| ; x_{2} \leq|m+r / 2| ; x_{3} \leq|m / 2|, j=1,2,3 . \\
& \sigma_{22}^{0 m}=\sigma_{22}^{0 a} ; \sigma_{21}^{0 m}=\sigma_{21}^{0 a} ; \sigma_{23}^{0 m}=\sigma_{23}^{0 a} ; u_{j}^{0 m}=u_{j}^{0 a}, j=1,2,3 \\
& \text { при } x_{2}=|m+r / 2|, x_{1}=\leq|l / 2|, x_{3}=\leq|m / 2| . \\
& \sigma_{33}^{0 m}=\sigma_{33}^{0 a} ; \sigma_{31}^{0 m}=\sigma_{31}^{0 a} ; \sigma_{32}^{0 m}=\sigma_{32}^{0 a} ; u_{j}^{0 m}=u_{j}^{0 a}, j=1,2,3 \\
& \text { при } x_{3}=|m / 2|, x_{1}=\leq|l / 2|, x_{2}=\leq|m+r / 2| .
\end{aligned}
$$

Условия затухания на бесконечности для матрицы имеют вид:

$$
\sigma_{i j}^{10 m} \rightarrow 0 ; u_{j}^{10 m} \rightarrow 0 \text { при } x_{i} \rightarrow \pm \infty, i=1,2,3 .
$$


Для решения задачи устойчивости необходимо найти векторную функцию $\bar{u}\left(x_{1}, x_{2}, x_{3}\right)$, удовлетворяющую в пределах армирующих волокон и матрицы уравнениям в возмущениях

$$
\left(\sigma_{i m}+\lambda \sigma_{i k}^{0} u_{m, k}\right)_{, i}=0,
$$

условиям затухания возмущений на бесконечности

$$
n_{i}\left(\sigma_{i m}+\lambda \sigma_{i k}^{0} u_{m, k}\right) \rightarrow 0, \bar{u}\left(x_{1}, x_{2}, x_{3}\right) \rightarrow 0, x_{i} \rightarrow \infty
$$

и условиям непрерывности векторов напряжений и перемещений на контакте компонент композита:

$$
\left[n_{i}\left(\sigma_{i m}+\lambda \sigma_{i k}^{0} u_{m, k}\right)\right]=0,\left[\bar{u}\left(x_{1}, x_{2}, x_{3}\right)\right]=0,
$$

где $[f(x)]=f(x-0)-f(x+0)$ - скачок функции $f(x)$.

Выражения (6) - (9) представляют собой обобщенную задачу на собственные значения, в которой критические компоненты определяются нахождением минимального по модулю собственного значения. Критическая нагрузка определяется из выражения

$$
P_{k p}=\min |\lambda| P,
$$

где $\min |\lambda|$ - минимальное по модулю собственное значение задачи (6) - (9); $P$ - интенсивность поверхностной нагрузки, приложенной на бесконечности к композитному материалу (рис.1).

Численное решение. Для построения вычислительного алгоритма решения задач (1) - (6) и (7) - (9) используется вариационноразностный подход [1], в соответствии с которым для расчетной схемы вводится по каждому из направлений $O x_{1}, O x_{2}, O x_{3}$ неравномерная разностная сетка $\bar{\omega}=\omega+\gamma$, состоящая из множества $\omega$ внутренних и множества $\gamma$ граничных узлов. Сетка разбивает расчетную область на $M$ прямоугольных параллелепипедов и содержит $N$ узлов, в каждом из которых строится аппроксимация диффреренциальных задач (1) - (6) и (7) - (9). Диффреренциальным задачам (1) - (6) и (7) - (9) на сетке $\bar{\omega}$ ставятся в соответствие разностные задачи:

$$
\begin{aligned}
& A y=\Phi, x \in \bar{\omega} ; \\
& A y=\mu B y, x \in \bar{\omega} .
\end{aligned}
$$

Построение задач (11), (12) осуществляется в соответствии с методикой, предложенной в [4]. Для решения дискретных задач (11), (12) использованы численные методы (прямые и итерационные) [1]. Для повышения эфрфективности рассмотренной методики использовалась 
динамическая разностная сетка и комбинированное применение прямых и итерационных методов.

Численные результаты. Результаты получены для полимерных материалов в интервале $10 \leq \mathrm{lm}^{-1} \leq 500$ изменения параметра $\mathrm{lm}^{-1}$. На рис. 2 представлена зависимость величины критической деформации композита $\varepsilon_{11}^{k p}$ от геометрического параметра $\mathrm{lm}^{-1}$ армирующих волокон для различных значений расстояния $r^{*}=r l^{-1}$ между ними при $E_{a} E_{m}^{-1}=300$. Кривые $1-3$ соответствуют значению критической деформации $\left|\varepsilon_{11}^{\kappa p^{a}}\right|$ в средней точке волокна, а кривые 4 - 6 - значению критической деформации $\left|\varepsilon_{11}^{\kappa^{m}}\right|$ на бесконечности. При этом кривые 1 и 4 соответствуют значению $r^{*}=0,01$; кривые 2 и 5 - значению $r^{*}=0,1$; кривые 3 и 6 - значению $r^{*}=1$.

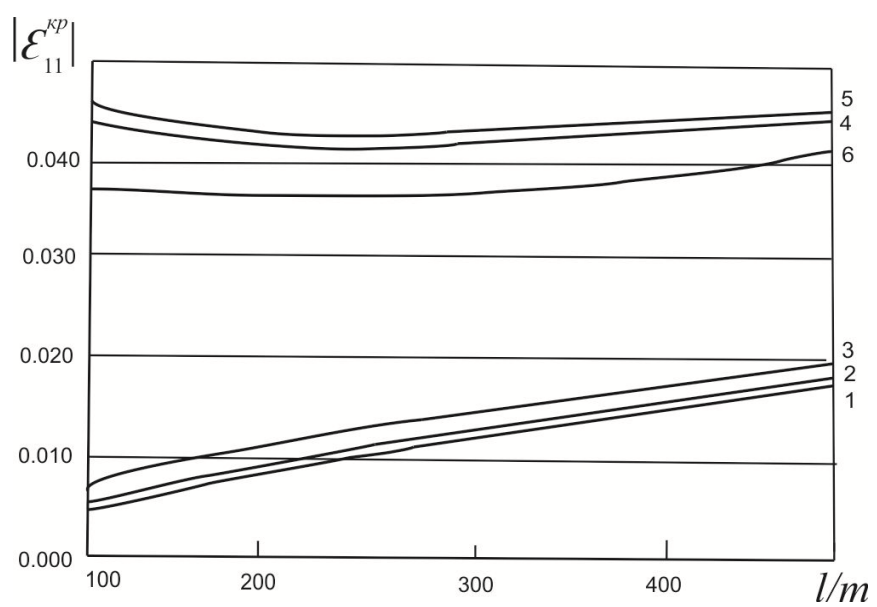

Рис. 2 - Зависимость критической деформации от геометрических параметров волокон

Выводы. Проведено сравнение полученных результатов с результатами работы [5], в которой исследовалось взаимодействие между двумя одинаковыми параллельными короткими волокнами в бесконечной матрице при плоской деформации. Как видно из полученных результатов, абсолютная величина критической деформации в средней точке армирующих элементов (волокон) как при плоской деформации, так и в пространственной задаче принимает значительно меньшие значения, чем в матрице на бесконечности для рассмотренных значений геометрических и механических параметров. Величины $\left|\varepsilon_{11}^{\kappa p^{a}}\right|,\left|\varepsilon_{11}^{\kappa p^{m}}\right|$, 
полученные в результате решения пространственной задачи, меньше соответствующих величин, полученных при решении плоской задачи. Различие для рассмотренных параметров $r^{*}=0,01 ; 0,1 ; 1$ составило соответственно 1\%, 3\%, 5\%.

\section{БИБЛИОГРАФИЧЕСКИЕ ССЫЛКИ}

1. Григоренко Я. М., Шевченко, А. Т. Василенко и др. Численные методы. Механика композитов: В 12-и т. / Под общей ред. А.Н. Гузя. Т.11. К.: “А.С.К.”, 2002. 448 с.

2. Гузь $\boldsymbol{A}$. $\boldsymbol{H}$. Основы трехмерной теории устойчивости деформируемых тел. К.: Вища школа, 1986. 512 с.

3. Гузь А. Н., Декрет В. А. О двух моделях в трехмерной устойчивости композитных материалов//Прикладная механика. 2008. Т. 44. №8. С. 3-31.

4. Гузь А. Н., Декрет В. А. Модель коротких волокон в теории устойчивости композитов. LAPLAMBERT Academic Publishing, 2015. $315 \mathrm{c}$.

5. Декрет В. А., Зеленский В. С., Быстров В. М. Устойчивость композитного материала, слабоармированного короткими волокнами // Пробл. обчисл. механіки і міцності конструкцій: зб. наук. праць. 2016. Вип. 25. С. 27-39.

6. Pissanetzky S. Sparse Matrix Technology. London: Academic Press, 1984. 321 p.

Удк 539.3

В. С. Зеленський, канд. фріз.- мат. наук,

В. А. Декрет, д-р фоз.-мат. наук, В. М. Бистров, канд. фріз.-мат. наук

\section{ПРОСТОРОВА ЗАДАЧА СТІЙКОСТІ КОМПОЗИТНОГО МАТЕРІАЛУ, АРМОВАНОГО ДВОМА ПАРАЛЕЛЬНИМИ КОРОТКИМИ ВОЛОКНАМИ}

3 використанням основних співвідношень тривимірної лінеаризованої теорії стійкості і моделі кусково-однорідного середовища розв'язана просторова задача стійкості композитного матеріалу з армуючими волокнами скінченних розмірів. Досліджено залежність критичної деформації композитного матеріалу від геометричних характеристик армуючих волокон. Проведено порівняння 3 результатами, отриманими в рамках моделі "коротких волокон". Для розв'язування задачі стійкості застосований числовий підхід на основі методу сіток.

Ключові слова: композитний матеріал, короткі волокна, критична деформація, тривимірна лінеаризована теорія стійкості, чисельний підхід.

UDC 539.3

$$
\begin{gathered}
\text { V. S. Zelenskii, PhD (Phys.-Math.), V. A. Dekret, Dr. Sci. (Phys.-Math.), } \\
\text { V. M. Bystrov, PhD (Phys.-Math.) }
\end{gathered}
$$

\section{SPATIAL PROBLEM OF STABILITY OF COMPOSITE MATERIAL REINFORCED BY TWO PARALLEL SHORT FIBERS}

Using the basic relations of the three-dimensional linearized theory of stability and the piecewise-homogeneous medium model, the spatial problem of stability of a composite material with reinforcing fibers of finite size was solved. The dependence 
of the critical deformation of a composite material on the geometric characteristics of reinforcing fibers is investigated. A comparison with the results obtained in the framework of the "short fibers" model is made. To solve the stability problem, a numerical approach based on the grid method was applied.

Key words: composite material, short fibers, critical deformation, three-dimensional linearized stability theory, numerical approach.

The study of the loss of stability in the internal structure of composite materials (CM) is the subject of work [3], in which, using the models of 'infinitely long fibers' and 'finite-size fibers', a comparative analysis of the results on the stability of $\mathrm{CM}$ obtained in the framework of a planar problem (plane strain) was performed. The work [4] presents specific results for composites of various structures, obtained in the framework of the model of short fibers. A number of model problems of stability of composite materials are investigated, mathematical methods for their solution, focused on computer implementation, are described. In [5], using the model of short fibers, the plane and spatial stability problems were solved for a single isolated reinforcing fiber in an infinite matrix under uniaxial compression. The results were obtained using the general equations of the three-dimensional linearized theory of the stability of deformable bodies (TLTDT) [2] and the model of a piecewise-homogeneous medium. This approach is the most rigorous and allows us to estimate the accuracy of the results obtained using various approximate theories and computational schemes. In continuation of the studies conducted in [3 - 5], in this paper we consider a composite material with reinforcing short fibers at their low concentration. The interaction between two parallel identical fibers, which are placed along the compressive load, is investigated. The problem is solved in spatial formulation. A relatively rigid composite material is considered, and therefore the second version of the theory of small subcritical deformations [2] is applied to solve the stability problem, when the subcritical state is determined by geometrically linear theory. The filler (reinforcing fibers) and the binder (matrix) are modeled by linearly elastic isotropic bodies.

In this paper, for the numerical solution of these problems the meshbased method based on modified variational-difference approach was used [1]. The discrete problems are solved using effective numerical methods and the following procedure outlined in [4]. The algebraic problem is solved with the direct Cholesky method. After the refinement of the difference mesh, the conjugate-gradient method is used. The solution found with the Cholesky method is interpolated and used as an initial approximation for solving the discrete eigenvalue problem by the subspace iteration method.

The obtained graphic information allows us to estimate the accuracy of the applied computational schemes associated with the choice of the computational domain, when performing strength calculations of composite specimens with the required accuracy. 


\section{REFERENCES}

1. Grygorenko Ya. M., Shevchenko Yu. N., Vasilenko A. T. et al. Computaional methods Mechanics of composites: In 12 volumes / Editor-in-Chief A.N. Guz. Vol.11. Kiev: A.S.K., 2002. 448 p. (in Russian).

2. Guz A. N. Fundamentals of three-dimensional theory of stability of deformable bodies. Kiev: Vysha Shkola, 1986. 512 p. (in Russian).

3. Guz A. N., Dekret V. A. About two models in three-dimensional stability of composite materials//Applied mechanics. 2008. Vol. 44. No. 8. P. 3-31.

4. Guz A. N., Dekret V. A. Model of short fibres in the theory of stability of composites. LAPLAMBERT Academic Publishing, 2015. 315 p. (in Russian).

5. Dekret V. A., Zelenskii V. S., Bystrov V. M. Stability of the composite material weakly reinforced by short fibres // Problems of the computational mechanics of strength and structures. 2016. Vol. 25. P. 27-39.

6. Pissanetzky S. Sparse Matrix Technology. London: Academic Press, 1984. 321p.

Інститут механІки ім. С. П. Тимошенка

НАН Україны,

Київ, Україна

Надійшла до редколеаії 03.10.2019 